Florida International University FIU Digital Commons

$11-9-2010$

\title{
The Crossroads of Eternality and Southern Distortion: An Analysis of Flannery O'Connor's Fiction
}

William J. Lisenbee

Florida International University, wlisenbe@fiu.edu

DOI: $10.25148 /$ etd.FI10120801

Follow this and additional works at: https://digitalcommons.fiu.edu/etd

Part of the English Language and Literature Commons

\section{Recommended Citation}

Lisenbee, William J., "The Crossroads of Eternality and Southern Distortion: An Analysis of Flannery O'Connor's Fiction" (2010). FIU Electronic Theses and Dissertations. 320.

https://digitalcommons.fiu.edu/etd/320 


\title{
FLORIDA INTERNATIONAL UNIVERSITY
}

Miami, Florida

\section{THE CROSSROADS OF ETERNALITY AND SOUTHERN DISTORTION: AN ANALYSIS OF FLANNERY O'CONNOR'S FICTION}

\author{
A thesis submitted in partial fulfillment of the \\ requirements for the degree of \\ MASTER OF ARTS \\ in \\ ENGLISH \\ by
}

William Joseph Lisenbee

2010 
To: Dean Kenneth Furton

College of Arts and Sciences

This thesis, written by William Joseph Lisenbee, and entitled The Crossroads of Eternality and Southern Distortion: An Analysis of Flannery O'Connor's Fiction, having been approved in respect to style and intellectual content, is referred to you for judgment.

We have read this thesis and recommend that it be approved.

$\begin{array}{r}\hline \text { Nathaniel Cadle } \\ \hline \text { Phillip Marcus } \\ \hline \text { Bruce Harvey, Major Professor }\end{array}$

Date of Defense: November 9, 2010

The thesis of William Joseph Lisenbee is approved.

Dean Kenneth Furton
College of Arts and Sciences

Interim Dean Kevin O'Shea

University Graduate School

Florida International University, 2010 


\section{DEDICATION}

I dedicate this thesis to my mom. Without her support and love, I would be lost. 


\section{ACKNOWLEDGMENTS}

I wish to thank the members of my committee for their kindness and assistance.

Dr. Nathaniel Cadle stepped in and provided wisdom and timely feedback, Dr. Phillip Marcus was often an encouraging voice, and Dr. Bruce Harvey, my major professor, was always prompt and consistently willing to accommodate my needs. I could not have found a better committee. 
ABSTRACT OF THE THESIS

THE CROSSROADS OF ETERNALITY AND SOUTHERN DISTORTION: AN

ANALYSIS OF FLANNERY O'CONNOR'S FICTION

\author{
by \\ William Joseph Lisenbee \\ Florida International University, 2010 \\ Miami, Florida \\ Professor Bruce Harvey, Major Professor
}

The purpose of this analysis was to explore how social and cultural values in the South determine meaning in Flannery O'Connor's fiction. Since Christianity is the predominant religion in the South, only O'Connor's stories with obvious Christian themes and characters were chosen.

Several modern literary theories, along with select criticism of O'Connor's literature, were used to investigate the fluidity of words and their corresponding meanings in O'Connor's fiction. Although Flannery O'Connor's language and depictions are often open-ended, there were definite bounds located, namely, Biblical allusions and Southern cultural standards.

These findings demonstrated that the language in O'Connor's fiction is neither an arbitrary system nor is it driven by the author's history or intent. It is, therefore, recommended that a cultural approach be applied to Flannery O'Connor's literature if the goal is to comprehend her religious themes. 


\section{TABLE OF CONTENTS}

CHAPTER

PAGE

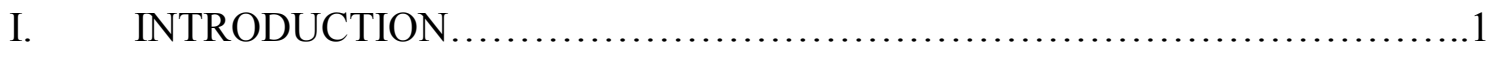

II. THE PROVINCIAL LANGUAGE OF THE SOUTH...........................

III. THE SIMPLICITY THAT IS IN CHRIST ................................15

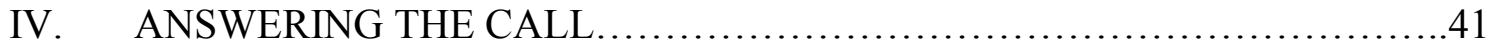

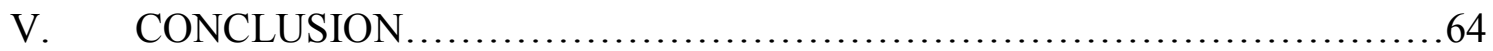

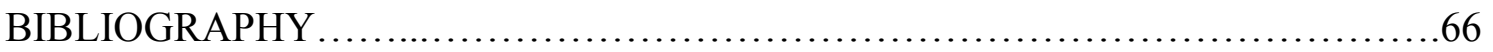


Chapter I: Introduction

Flannery O'Connor's stories have been inspiring to me in several ways, so perhaps the best preface for this thesis is an anecdotal one. To be sure, her fiction is especially significant because I first read her short story "Parker's Back" soon after my conversion to Protestant Christianity. In this short story, the protagonist O. E. Parker struggles to find his identity amid the religiosity of the South. In an effort to assuage his growing discontent, Parker first marks his body with tattoos and then joins the Navy, but it is to no avail. The disconsolate Parker is dishonorably discharged, and he thereafter returns to the South where he converts to Christianity in order to solve his "spiritual" quandary, only to find that his acceptance of Jesus Christ does not create the spiritual kinship that he expects.

In graduate school years later, I was assigned to read O'Connor's “The Displaced Person," which is a vivid depiction of self-preservation in the South and "the narrowness which accompanies and colors it for the outside world" (O'Connor, Collected 856). One character in particular resonates with me because she, Mrs. Shortley, typifies a selfrighteous Christian. The phrase self-righteous Christian is oxymoronic, for by virtue of being a Christian, one should deprecate his own supposed goodness. A faithful Christian is to rely solely on Jesus Christ for his/her righteousness and, if necessary, vindication. Yet the type of self-justifying behavior found in Mrs. Shortley is unfortunately present in many churchgoers across the South.

What struck me as a bit odd as I discussed these stories with my collegiate peers was that other students were not gleaning O'Connor's fiction, nor were they valuing her characters, for the same reason I was. I found her stories to be rich in both Christian 
meaning and psychological detail, so presumably, I understood O'Connor's characters in ways that others did not. I initially attributed this discrepancy to my classmates being unacquainted or unfamiliar with the Christian Scriptures. O'Connor's stories will often allude to or parallel Biblical passages, and I, a religious reader to a degree, chose to focus on these instances. However, through my studies for this thesis, I have learned that it is not just a belief in or familiarity with the Bible that will empower a Flannery O'Connor reader. Since language is socially constructed, it is the entire culture of the South that informs O'Connor's fiction, and unfortunately, it is this cultural knowledge, that is, says O'Connor, "the local and the particular and the familiar" (Collected 844), that is increasingly lacking in many of O'Connor's modern readers. Indeed, O’Connor's characters possess an awareness of Southern principles that is not always matched by O'Connor's readership.

This is not a scathing criticism, nor is it to assert that interpretations or close readings of O'Connor's fiction that do not take into account Southern norms are somehow false. It is, rather, the stating of a problem, for although O'Connor's work can rightfully be viewed from numerous perspectives, her quirky, stark depictions of religious life in the South distinguish her form of Southern fiction and thus merit analysis. Indeed, O'Connor's characters are often quickened by Southern cultural values, and with an acute knowledge of these values comes a deeper understanding of many of her characters.

For example, as I analyzed for this thesis O’Connor's longest and darkest work The Violent Bear It Away, I was deeply affected by how the protagonist, Francis Marion Tarwater, typifies Southern Protestants. Young Tarwater is homeschooled by his aged and rather rabid great-uncle, whose primary intent is to protect the boy from the wages of 
sin. However, Tarwater's great-uncle takes an extreme position by forsaking contemporary educational standards. The tragic result is an isolated teenager who, although much is expected of him, is both mentally disturbed and unable to adapt to what he sees and hears outside of his rural environment.

Tarwater's upbringing and subsequent behavior are a distortion of a small but very real population in the South, to wit, so-called "preacher's kids." These children are raised by parents who take on or accept a vocal role in their local churches, whether it involves preaching in the pulpit or publicly on street corners; the children of these zealous Christians are often directed and trained in a separatist fashion (e.g., homeschooled) lest they be contaminated by worldly influences. Their parents know fully well the consequences of being "alienated from the life of God" (Authorized Version, Eph. 4.18), many having emerged or been "saved" out of a dark hour. These parents in turn take great care in admonishing their children and, likewise, shielding them from sin and carnality.

There is, however, a potential strain in this type of upbringing. That is, if these children are to mature as Christians, they must identify themselves with Biblical principles, and this necessitates understanding, and therefore confronting in some manner, the corrupting influences which they have been safeguarded from. O'Connor understands this quandary and observes that "some kind of loss is usually necessary to turn the mind toward faith." In other words, true Christian repentance will not occur if one is enthused about his/her lot in life (Habit 159). Tarwater's travails are indeed indicative of the dilemma of a pastor's child, particularly in the South, and his dark and complex trek toward the city, for example, surely would not be as meaningful to me had I 
not been cognizant of the predicament that preachers' children face. Likewise, many of O'Connor's characters would not be as significant, I want to stress, had I not viewed them through the context of Southern Christianity. This thesis was written to explore and to demonstrate how such a perspective can enrich a close reading of Flannery O'Connor's fiction. 
Chapter II: The Provincial Language of the South

Flannery O'Connor represents an important voice in American literature because her works offer to readers, among other things, an acute, satirical perspective of the Bible Belt. Undoubtedly, the profundity of her writing is due in large part to O'Connor being a devout Roman Catholic adherent residing in the traditionally Protestant South. Her Catholicism and the South as a locale make for an interesting blend; both are integral parts of her fiction. O'Connor indicates this when she states, "I'm interested in the old Adam. He just talks Southern because I do" (qtd. in Sherry 29). Nevertheless, O'Connor's fiction elicits a wide range of responses, practically encouraging readers to plumb meaning from numerous perspectives (e.g., psychological, social or cultural, and theoretical), and it is precisely this dynamic quality to her literature that has allowed Flannery O'Connor to become one the most anthologized female writers in the U.S.

However, part of O'Connor's charm is that she is a regional fiction writer who is fiercely loyal to the culture of the South. O'Connor in fact asserts that the South has had an inestimable influence upon her writing:

The South impresses its image on the Southern writer from the moment he is able to distinguish one sound from another. He takes it in through his ears and hears it again in his own voice, and, by the time he is able to use his imagination for fiction, he finds that his senses respond irrevocably to a certain reality, and particularly to the sound of a certain reality. The Southern writer's greatest tie with the South is through his ear, which is usually sharp but not too versatile outside his own idiom. With a few exceptions... he is not too often successfully cosmopolitan in fiction, but 
the fact is that he doesn't need to be. A distinctive idiom is a powerful instrument for keeping fiction social. When one Southern character speaks, regardless of his station in life, an echo of all Southern life is heard. This helps to keep Southern fiction from being a fiction of purely private experience. (Collected 855 )

Southern life is marked by a Biblical enthusiasm which is innately grotesque to those who are averse to the form of Christian evangelism so prevalent in the South. Outward showings of this enthusiasm are often intense and forceful, therefore not congenial to some. Flannery O'Connor, however, finds inspiration in the South's Protestant fervor, even the unique idiom which accompanies it. For although she espouses a distinct Catholic system of Biblical interpretation, her personal beliefs overlap many of the principles of the street preachers or so-called shouting fundamentalists whom she encounters in the South. Her stated goal as a novelist is to advance Catholic fiction by making "belief believable" (Collected 857). That is to say, O'Connor wishes either to introduce a reader to or deepen a reader's awareness of Christian theology. And the South, a region where residents do "hold a sacred history in common" (O'Connor, Collected 858), affords O'Connor a concrete social setting with which to accomplish this.

Flannery O'Connor's oeuvre is consequently driven by a community of believers (i.e., a cast of faith-based characters), and her religious themes are clearest only when this community's complex interrelationship with Southern culture is analyzed. Intently concerned with how others read and interpret her fiction, Flannery O’Connor strongly supports this cultural view of her literature. She explains, "Fiction is supposed to represent life, and the fiction writer has to use as many aspects of his life as are necessary 
to make his total picture convincing. The fiction writer doesn't state, he shows, renders. It's the nature of [regional] fiction and it can't be helped" (Habit 143). Her characterscontrary to the contemporary hero whose experiences, O'Connor contends, are neither rooted in nor indicative of any particular culture (Collected 856) - are thus informed by Southern mores. These mores or values are not always easily understood outside of the religiously-inclined region of the South, nor should they be. They belong to a growing minority population in the U.S., a populace that distrusts earthly governments as well as anti-Biblical principles. Residents of this community have not learned only abstract definitions of faith and obedience, but "have trembled with Abraham as he held the knife over Isaac" (O’Connor, Collected 859). They subsequently see themselves as pilgrims, led "into the modern world with an inburnt knowledge of human limitations and with a sense of [Christian] mystery" (O'Connor, Collected 847). Indeed, it is this humbling recognition coupled with a strong Biblical background which makes the Protestant South socially unique.

Because of the distinct manners informing Flannery O'Connor's brand of Southern fiction, there are certain cultural bounds that O'Connor recognizes and meets as a creative artist. However, far from being a literary constraint, these bounds are a great blessing she claims, for they are a "gateway to reality" (Collected 844). Contemporary literary theorist Terry Eagleton explains that both the reading and writing of fiction are by nature a "constrained affair" because words are often used by people in their social practices of communication in exclusive ways, and these practical social uses then become an idiom (75). Eagleton emphasizes the ultimate fluidity of words and their corresponding meanings, but he cautions that since a person's experience "is social to its 
roots...there can be no such thing as a private language, and to imagine a language is to imagine a whole form of social life" (53). O'Connor's blessing is thus manifest: the social and cultural practices of the South furnish the very language to her stories, and this in turn provides O’Connor a local readership that understands her appeals and grotesque characterizations. Indeed, O'Connor's use of theology in concert with impulsive, violent behavior does not need the explanation in the South as it may elsewhere. Southern readers who study the Bible and see life through a Biblical lens are generally not dismayed by the conjoining of violence and religious enthusiasm, even O'Connor's wellwishing statement to the Fitzgeralds that their child "have a fierce Old Testament name and cut off a lot of heads" (Habit 26). In short, Flannery O'Connor appreciates writing about the South because her religiously zealous characters, as well as the words and images that motivate them, are not exactly aberrations "in the Bible Belt, where such people... are taken for granted" (Collected 857).

O'Connor's identity as a Southern religious writer is to a degree a function of her rather contrary experiences while studying and writing abroad. That is to say, both the critics of her early work and the adverse milieu that O'Connor encounters in the North help her to grow into a fine Southern novelist.

From the outset of her career, O'Connor finds that her fiction is interpreted in ways that she does not intend. For example, while at a writers' workshop in graduate school, O'Connor hears an established poet's reading of one of her pieces and is soon disappointed that he, John Crowe Ransom, founder and editor of the Kenyon Review, substitutes the word Negro for nigger. According to O'Connor, this short piece was supposed to render the actual dialogue of poor folks in the South. However, Ransom's 
alteration spoils the depiction, discrediting the language system out of which her short story is produced. O'Connor notes, "The people I was writing about would never use any other word" (qtd. in Gooch 125).

O'Connor's earliest experiences with a professional publisher are similarly disappointing. After receiving feedback from the New York-based publisher Rinehart and Company concerning a manuscript of her first novel Wise Blood, Flannery O'Connor is incensed by its editors' unwillingness (namely, John Selby, who states that he is not pleased with O'Connor's "hardening of the arteries of her cooperative sense" [qtd. in Gooch 164]) to accept her writing as is. She says that "the thought of working with [Rinehart's editors] specifically to correct these lacks they mention is repulsive to me" (Habit 9). Her complaint is certainly not against revision and rewriting. It is against those editors, O'Connor contends, who ignore "what [she is] trying to do," and who in turn diminish her Southern perspective for the sake of producing and profiting from "a conventional novel" (Habit 10).

These responses, O'Connor discovers, are not at all atypical, but are indicative of the reception of her literature by readers who are not intimately familiar with her Southern background. What is more, readers such as these seem too willing to categorize O'Connor's fiction according to “common" literary standards. Of course O'Connor, sensitive to the varied responses of her readers, initially laments the classifying of her work, particularly because of how restrictive labels can be: "I find myself in a world where everybody has his compartment, puts you in yours, shuts the door and departs" (Habit 92). Yet her affinity for the Protestant South as a literary setting and likewise her determination as a creative writer in part develop because of the adverse reactions to her 
early work.

O'Connor's social environment in the North has its part in shaping and emboldening her will as an author as well. Immediately after graduate school, for example, O'Connor attends a summer residency program at the Yaddo artists' colony in Saratoga Springs, New York. This summer program is intended to furnish a supportive atmosphere where creative artists of various types can develop their work without interruption. However, O'Connor finds Yaddo to be less than ideal, for artists there frequently have raucous parties and brazenly speak of their use of barbiturates (Gooch 152). O'Connor's religious values clearly distinguish her from many of the writers and artists whom she encounters, yet she manages to mature in this environment and, she says, "survive... by not being afraid to be different from the rest of them" (qtd. in Gooch 152). She continues to write and consequently turns to what she is most familiar with, incorporating or weaving the South into her fiction. O'Connor resolves, "I think the quality of the novel I write will derive precisely from the peculiarity or aloneness, if you will, of the experience I write from" (Habit 10).

O'Connor's experiences and encounters while studying abroad practically move her to value stalwart residents of the South. That is, she learns to covet Southerners as both sources of inspiration and insightful readers. O'Connor's theoretical audience may indeed be the irreligious scholar, for she states, "At least [this is the person] I am conscious of writing for" (Habit 92), but she nonetheless learns that a "writer whose themes are religious needs a region where these themes find a response in the life of the people" (O’Connor, Collected 857). In this analysis, O’Connor's “spiritual” characters will thus be interrogated and explored, and to justify this study, the use of several 
theoretical principles will be used.

Intertextuality, for one, will illuminate or foreground the Bible's influence, "as well as those aspects of Southern life where the religious feeling is most intense" (O'Connor, Collected 859). The term intertextuality, which first enters the French language in Julia Kristeva's criticisms of the 1960s, signifies the intricate interrelationship between a given text and other texts. This concept is not merely a feature or literary device found within certain fictional works. It is a profound principle that can, in many instances, create and/or liberate the author-reader relationship. According to Graham Allen, author of the book Intertextuality, application of this property forces readers to reconsider the very nature of a written work:

No longer the product of an author's original thoughts, and no longer perceived as referential in function, the literary work is viewed not as the container of meaning but as a space in which a potentially vast number of relations coalesce. A site of words and sentences shadowed by multiple potentialities of meaning, the literary work can now only be understood in a comparative way, the reader moving outwards from the work's apparent structure into the relations it possesses with other works and other linguistic structures. (12)

Allen carefully adds that comparison may be a misnomer, for intertextuality does not just denote the reading of one work of literature in relation to other works. It is more specifically the "registering of the relational position of signs and works within [linguistic-cultural] systems of meaning" (12). Thus, O'Connor's literature does not have definite boundaries, for a literary text is essentially a product of other literary texts, and 
not just in the sense that it contains or is comprised of allusions to other works. Indeed, even individual words or phrases are potentially informed by associated works of art.

The ideas of French critic Roland Barthes are also significant in this study. In his controversial essay "The Death of the Author," Barthes posits that since "language ceaselessly calls into question all origins" (256), no text stands alone. That is, a literary text is not fixed; it cannot possess a definite meaning. It is rather "a multidimensional space in which a variety of writings, none of them original, blend and clash. A text is a tissue of [signs, references, and] quotations drawn from...innumerable centers of culture" (Barthes 256). The writing of literature itself then is an activity given to multiplicity, for writing enters "into mutual relations to dialogue, parody, [and] contestation," and if a unity does exist, it does not lie in a text's “origin but in its destination" (Barthes 257).

Consequently, the reader is the primary focus in this analysis, not O'Connor's authorial intent nor her history. In other words, the reader can be just as pivotal as O'Connor because it is not simply the author who is speaking, but language itself, "in all its swarming 'polysemic' plurality...If there is any place where this seeming multiplicity of the text is momentarily focused, it is not the author but the reader" (Eagleton 120). Perhaps as a creative writer O'Connor would object to the totality of this position, but she does admit, interestingly enough, that even she does not know the full meaning of her stories: "I won't ever be able to entirely understand my own work or even my own motivations" (Habit 92).

Finally, a Heideggerian view of language will also provide a premise here. It shall be shown that certain of O'Connor's characters have their existence or authenticity only through language. That is to say, language for these characters has an existence of its 
own, and only by embracing language and, thus, the society in which they live, do these Southern characters come into their true being or eternal identity.

I argue that interpretive methods that ignore or devalue the Southern religious values present in many of O'Connor's characters in fact limit the process of analysis. This may occur, for example, when secular concerns or issues are overemphasized, for a "secular society understands the religious mind less and less" (O'Connor, Collected 859). To be sure, readers may discover more about O'Connor's fiction if the culture of the South is appropriately analyzed during close readings of her stories. This thesis seeks to do just that.

Thus, in the succeeding chapters I will explore Flannery O'Connor's Christian characters. Indeed, there are elements of the Christian faith in many of O'Connor's characters, but my focus is on the characters for whom faith—in particular a saving or life-altering faith—is central to their identity. I will present these characters via a progression in complexity from least to greatest (i.e., from immature to knowledgeable), and in the process, several of Flannery O'Connor's short stories will be critiqued (in the following chapter), along with her novel The Violent Bear It Away (in the fourth chapter).

First, Mrs. Shortley in "The Displaced Person" will be analyzed because her epiphany immediately before the end of her life is a type of conversion to Christ. Then, Mrs. Turpin in "Revelation" will be explored because she, too, experiences a type of conversion, and her epiphany sort of builds on Mrs. Shortley's. That is, it details the new testament principle "of repentance from dead works" (Heb. 6:1). O.E. Parker in "Parker's Back" will be examined next, for his life presents a profound picture of Christianity in the South, and in turn, Sheppard in "The Lame Shall Enter First" will be analyzed, for his 
family tragedy is representative of the South's Christian apostasy, to wit, a time of religious and moral declension. Finally, Francis Tarwater, the protagonist in The Violent Bear It Away, will be critiqued. Although Tarwater is O'Connor's darkest and most disturbing characterization, his trials present a clear picture of a Christian's call to the ministry. 
Chapter III: The Simplicity That Is in Christ

The problematic interpretative issues within O'Connor's fiction are contingent upon her audience. That is to say, if O'Connor's reading audience is a believing one who stands dearly in the same religious system as she, then interpretive problems will largely cease. This type of Christian reader will presumably understand or be acquainted with O'Connor's authorial intent and may use this knowledge as a means to discover or interpret the meaning of O'Connor's stories. However, O'Connor's readership is comprised of a variety of perspectives and backgrounds (she notes that her contemporary audience includes scholars and theological students as well as those in mental institutions [Habit 91]), and this diversity is particularly why there is such an immense amount of literary criticism concerning her fiction.

Nevertheless, the predominant strain of criticism seeks to interrogate and answer O'Connor's short stories through her brand of Christianity and her religious motivations. There is a consistency in this. Emphasizing the author's interiority and/or history is often warranted, especially when a work of fiction stems from a Catholic author who derives her stories from her own "aloneness" or alien experience in the Protestant South (Habit $10)$, and who argues that "the only way to make people see [eternal truths]" is by way of religious distortion (Habit 79). However, by emphasizing O'Connor's presumed authorial intent, readers are unfortunately diminishing the spiritual quality/insight of O'Connor's religious characters.

The type of Christianity, unorthodox and unsightly though it may be, evidenced by many of O'Connor's Southern characters certainly merits investigation. O'Connor consistently uses as a basis for her religious characters not the Roman Catholicism that 
she is so devoutly supportive of, but Southern Protestantism. A reason for this choice is made known by O'Connor in her correspondence with a fellow Roman Catholic: ...if you are a Catholic and have this intensity of belief you join the convent and are heard no more; whereas if you are a Protestant and have it, there is no convent for you to join and you go about the world getting into all sorts of trouble and drawing the wrath of people who don't believe anything much at all down on your head...This is one reason why I can write about Protestant believers better than Catholic believers-because they express their belief in diverse kinds of dramatic action which is obvious enough for me to catch. (qtd. in Orvell 43)

In short, fervent Protestants in the South generally have a vocal and outward nature, and this suits O'Connor's literary efforts. Therefore, failing to closely read the passages where her more outwardly religious characters inform a given plot is to undervalue the distinctly Protestant nature of her fiction. When her stories are limited in this way, the spiritual depth of her stories and certainly her characters is veiled.

Indeed, definite Christian/Biblical denotations, even ones that are perhaps unknown to Flannery O'Connor, can arise from closely reading her fiction. Yes, on the one hand, to explore or to find meaning in O'Connor's stories is to query her intentions to didactically reflect Catholic dogma, but on the other hand, a reader, Christian or otherwise, should not be limited to just exploring what O'Connor's very own religious motivation means to a particular passage or story. There is often a delicate balance in O'Connor's fiction between Catholic didacticism and principles of "universal human interest" (O'Connor, Collected 857), but critics who focus on the former, and declare her 
fiction to be "subliterary" because it "champion[s] a particular position or population or recipe for authenticity" (Lutz 57), suffer loss. They inevitably compartmentalize her fiction and limit its overall value. Concerning her use of Catholic dogma, O'Connor states, "Dogma can in no way limit...For me a dogma is only a gateway to contemplation and is an instrument of freedom and not of restriction. It preserves [religious] mystery for the human mind" (Habit 92). Flannery O'Connor was well aware of how various audiences may limit her fiction by attaching "a different meaning to it than [she]" (92), but O'Connor would not be indifferent to variant readings that do logically support Christian mystery or, what may be termed, faith in the eternal.

Nowhere is this mystery more evident in its initial stage or inception (indeed, there is a fleeting glimpse of it) than in Mrs. Shortley of Flannery O'Connor's "The Displaced Person.”

At the outset, Mr. Shortley is self-righteous and bigoted, and she reacts with cunning to justify her family as well as herself. For instance, she is quick to compare her son H.C. to Guizac's son, and of course with Mrs. Shortley authoring the comparison, "H.C. came out far ahead. H.C. was twenty years old with her build and eyeglasses. He was going to Bible school now and when he finished he was going to start him a church. He had a strong sweet voice for hymns and could sell anything" (O'Connor, Collected 288). Additionally, she seeks to establish her husband's good name and, in turn, sow discord between Mrs. McIntyre and the diligent Mr. Guizac. Mrs. Shortley asserts, "It is no man that works as hard as Chancey, or is as easy with a cow, or is more of a Christian" (296; emphasis added). The deceitful nature of this statement is evident, for although Chancey Shortley does not exhibit behavior or a work ethic that is remotely 
Biblical, Mrs. Shortley tries to persuade her employer by claiming an identity for her husband that Mrs. McIntyre is perhaps sympathetic to. Lastly, despite her feelings that religious worship and faith in God are "essentially for those people who didn't have the brains to avoid evil without it" (294) — organized religion she believes is merely "a social occasion providing the opportunity to sing" (294) — she ends up turning to "her Bible with new attention" (300). However, Mrs. Shortley doubtlessly uses her new understanding of the word of God, specifically the Apocalypse, to shore up the beliefs she already has against any and all actions on the farm that do not support her family's well-being. The carnality of Mrs. Shortley heightens the dramatic tension in "The Displaced Person" and illuminates for the reader the momentous change that is to soon take place in Mrs. Shortley's mind.

After seeing and hearing a presumed providential revelation, Mrs. Shortley prophesies, "The children of wicked nations will be butchered" (301). She thereafter walks up the road to where Mrs. McIntyre and the priest are conversing and overhears Mrs. McIntyre tell of her intention to give Mr. Shortley his month's notice. With her “face....an almost volcanic red" (303), Mrs. Shortley immediately enlists her family's help to pack up their belongings, and though it "took them the rest of the afternoon and half the night to do this...Mrs. Shortley was determined that they would leave before four o'clock in the morning, that Mr. Shortley should not adjust another milking machine on this place" (303).

The Shortleys finish packing into their car and begin to leave the farm in a whirlwind, and just as Mrs. Shortley thrashes and clutches "at everything she could get her hands on and hugging it to herself" (304), her fierceness fades. Instead of a woman 
fully in command of not only her faculties but her family's circumstance as well, what the reader is left with is a docile, debased Mrs. Shortley lying completely still. It is at this precise moment, amid the incessant clamoring of her two girls, that Mrs. Shortley receives her spiritual birth, as it were: "her huge body rolled back still against the seat and her eyes like blue-painted glass, seemed to contemplate for the first time the tremendous frontiers of her true country" (305).

This very moment in "The Displaced Person" is arguably the most ambiguous, as well as the most arresting, portion of the novella. However, Abraham's sojourning in the Bible adds clarity and significance to the sudden death of Mrs. Shortley, for both Mrs. Shortley and the patriarch Abraham have seminal roles in their respective stories. After Mrs. Shortley passes, Chancey Shortley develops a religious fervor, albeit hypocritically, and he uses the memory of his wife to fuel his new resolve; centuries after Abraham's death, errant Christians in Galatia are admonished and inspired by Abraham's role as their spiritual mentor (Gal. 3.6-9). Moreover, both Mrs. Shortley and Abraham are compelled to move from their respective dwelling places. In a sense, they are both, unbeknown to those around them, displaced. Mrs. Shortley has "been displaced in the world from all that belonged to her" (305), and Abraham obeys a call "to go out into a place which he should after receive for an inheritance.... and he went out, not knowing whither he went" (Heb. 11.8). Lastly, both parties die in faith. Before they expire, each looks, to some degree, to God for direction and guidance. As a result of their peculiar experiences, both understand that they are "strangers and pilgrims on the earth...For they that say such things declare plainly that they seek a [true] country" (Heb. 11.13-14).

To be sure, without cross referencing Abraham's experience from the Bible- 
which Flannery O'Connor as well as Southern readers would likely be mindful of-Mrs. Shortley's sudden contemplation of her true country (i.e., her crucial step of faith) is obscured. In short, the profundity of Mrs. Shortley's life-obtaining realization, her entrance into what O'Connor identifies as eternal mystery, is lost.

In many ways, Mrs. Ruby Turpin's experience in Flannery O’Connor's short story "Revelation" resembles and builds on Mrs. Shortley's. Indeed, Mrs. Turpin's rather dramatic epiphany, her own outstanding moment of lucidity, further illuminates the aforementioned mystery at work.

Like Mrs. Shortley, Mrs. Turpin initially appears as the embodiment of obstinacy and self-righteousness. She, too, habitually passes judgment on those around her (though her motive is not as practical as Mrs. Shortley's). While assisting her husband on his visit to a doctor's office, Mrs. Turpin immediately observes a young child sitting in the waiting area and presumes the child is uncared for, for she sees "at once that no one was going to tell him to move over... [and] his nose ran unchecked" (O'Connor, Collected 633). Clearly, Mrs. Turpin's judgment here is rash, for it is based on little more than the outward appearance of this child. Outward appearance, it would seem, is something that Mrs. Turpin is a slave to; resisting judgment by investigating the inward character of a person is not Mrs. Turpin's wish. Thus, she continues in her typical fashion to assess or size up the occupants of the waiting room:

Next to the ugly girl was the child, still in exactly the same position, and next to him was a thin leathery old woman in a cotton print dress. She and Claud had three sacks of chicken feed in their pump house that was in the same print. She had seen from the first that the child belonged with the old 
woman. She could tell by the way they sat — kind of vacant and whitetrashy, as if they if they would sit there until Doomsday if nobody called and told them to get up. (635)

Mrs. Turpin's simple internal judgments against others, in effect, validate and justify her own existence. Indeed, this type of judgmental, condemnatory attitude is present in several of O'Connor's characters, so it is not difficult to conclude that Mrs. Turpin actually believes that the following lyrics to the gospel hymn playing in the background are applicable to her: "When I looked up and He looked down...And wona these days I know I'll we-eara crown" (635). Mrs. Turpin's singing of these lyrics amounts to a revealing admission: implicit is Mrs. Turpin's belief that she, for her faithful Christian service, is righteous and therefore deserving of a crown.

The New Testament principle of inheriting crowns for proper stewardship, among other things, is mentioned periodically throughout the Pauline and General epistles. In one instance, the apostle Paul writes,

For though I be free from all men, yet have I made myself servant unto all, that I might gain the more...I am made all things to all men, that I might by all means save some. And this I do for the gospel's sake, that I might be partaker thereof with you. Know ye not that they which run in a race run all, but one receiveth the prize? So run, that ye may obtain. And every man that striveth for the mastery is temperate in all things. Now they do it to obtain a corruptible crown; but we an incorruptible. (I Cor. 9.19-25) Paul's exhortation to the Christian, in short, is to continue with wisdom in his/her personal ministry. Those who strive and remain in the ministry of the gospel of God's 
grace (i.e., those who finish the race) will be rewarded with an incorruptible crown. This particular crown is, thus, connected with being a faithful Christian witness until the end of one's life.

Unlike Mrs. Turpin, however, the apostle Paul is not presumptuous. He does not know what will befall him and, to be sure, does not tout his own faithfulness. Paul never professes to be spiritual. On the contrary, he acknowledges that he is essentially weak and carnal (Rom. 7.14). Although Paul is careful not to diminish without warrant the state and, therefore, rewards of other Christians - he indeed encourages his brethren when he declares, "But, beloved, we are persuaded better things of you, and things that accompany salvation" (Heb. 6.9) —what Paul does not possess is certainty over his own future inheritance.

Every Southern Bible believer "in Christ" would do well to hope as well as strive for a crown, but to admit or to believe inwardly that a heavenly reward is certain is definitely presumptuous. Mrs. Turpin's confidence is especially unwarranted: there is no textual evidence of her being a selfless witness of the gospel. And even when she does publically express in the waiting room a measure of the so-called by O'Connor 'intensity of belief" (qtd. in Orvell 43), Mrs. Turpin manages to praise and exalt herself via her warped thanksgiving to God: "I thank the Lord he has blessed me with a good [disposition]" (643). Moments later she continues, "If it's one thing I am...it's grateful. When I think who all I could have been besides myself and what all I got, a little of everything, and a good disposition besides, I just feel like shouting, 'Thank you, Jesus, for making everything that way it is!'” (644). Mrs. Turpin's bombastic behavior reveals the high estimation she has for herself. However, her assurance is misplaced, for the 
corporal body, that is, the nature of man, is flatly spoken against in the Christian Scriptures: "I know that in me (that is, in my flesh,) dwelleth no good thing: for to will is present with me; but how to perform that which is good I find not" (Rom. 7:18); the "way of man is froward and strange" (Pro. 21.8).

Mrs. Turpin's perverted piety provides one-half of the unfolding tension in the doctor's office while Mary Grace's distinctly modern influence provides the other half. Ostensibly, the climax of "Revelation" occurs when Mrs. Turpin is struck with Mary Grace's secular book. It is revealing and not at all ironic that Mary Grace's book is titled Human Development: Mrs. Turpin's humanity is exposed in part by juxtaposing Mary Grace's textbook with the pharisaical aspects of the South.

The textbook, as well as its origin perhaps, is an object of contempt to not only Mrs. Turpin (undoubtedly a result of her rather Southern sensibilities), but to the author O’Connor as well. As an undergraduate, Flannery O’Connor develops a disdain for social science, even describing it as rotten (Habit 19). O'Connor says, "I read works of socialscience, so-called. The only thing that kept me from being a social-scientist was the grace of God and the fact that I couldn't remember the stuff but a few days after reading it" (Habit 98). Despite her negative sentiment, O'Connor has become familiar with the works of secular authors, the psychiatrist Carl Jung, for instance, and though O'Connor cleaves to the South for its Biblical inclination and religiously fertile ground, she is not at all a dull or backward thinker. It is possible then that the incorporation of this rather antiSouthern element, namely, Human Development, into the plot line of "Revelation" is Flannery O'Connor's subtle way of critiquing modern psychology. What is certain though is that Mary Grace's textbook is disconcerting to the Southern characters in 
"Revelation." It represents an alien community and culture.

Likewise, Massachusetts, the location of Mary Grace's Wellesley College and thus where Mary Grace obtained her textbook in all likelihood, represents to these Southern characters something modern and thus out of order. Their reaction to the very mentioning of Massachusetts is indeed telling. Mary Grace's mother grimaces and Mrs. Turpin subsequently murmurs, "Way up north" (643). Similarly, in "The Displaced Person" Mrs. Shortley finds the priest and the Guizacs' foreignness agitating: “The trouble with these people was, you couldn't tell what they knew. Every time Mr. Guizac smiled, Europe stretched out in Mrs. Shortley's imagination, mysterious and evil, the devil's experiment station" (296). Massachusetts, the North, and Human Development, as well as Europe and Roman Catholicism, all denote something dark and dangerous to these Southerners. That is, they are all sources of heresy or anti-Biblical principles, and Mrs. Turpin's selfish image is further developed by her exposure and reaction to each.

Despite her increasingly caustic behavior, however, Mrs. Turpin's motive in the doctor's office should not be reduced to simple self-validation. Her baser motive is to safeguard her Southern values and, in effect, secure her supposed virtue. Her concerns are not necessarily material, as are the Shortley's, and contrary to either of the Shortleys, hypocrisy is not her principal trait. Mrs. Turpin is to some degree sincere and enthusiastic about her religious beliefs. However, because she is hasty and not given to circumspection, Mrs. Turpin typifies "the comforters of Job, reasonable-seeming but wrong" (648). The express reference in "Revelation" to Job's friends is significant, for a comparison study of Job's dilemma will indeed shed light on the true climax of "Revelation" (i.e., Mrs. Turpin's pivotal realization). More specifically, by first 
associating Mrs. Turpin with Job's antagonizing friends and then Job himself, readers gain insight into the evolution of Mrs. Turpin's psyche.

The initial view that readers have of Mrs. Ruby Turpin best resembles Job's friends. For like the comforters of Job, Mrs. Turpin is much too willing to reprove others by offering them her conceptions about the Lord's will. Being vocal about one's faith is often appreciated in the South, but Mrs. Turpin, while professing to maintain good works, thinks in a damagingly exclusive manner: "She never spared herself when she found somebody in need, whether they were white or black, trash or decent" (642). Job's friend Eliphaz the Temanite has a comparable idea in mind while he reproves Job: "Remember, I pray thee, who ever perished, being innocent? Or where were the righteous cut off?" (Job 1.7). Eliphaz' implicit argument here is that Job is culpable in some way and is therefore suffering at the hand of God. Eliphaz' tragic flaw is manifest: he cannot think but in a binary fashion. That is, Eliphaz cannot conceive of how such a horrible affliction can be placed upon Job if not for the punishment of sin. Accordingly, Eliphaz' vision or, rather, ability to comprehend the mysterious/unseen things around him is limited. He is unaware of Job's spiritual trial at the hand of God, and he cannot see Job's inner thought process, yet this does not stop him from admonishing Job: "I would seek unto God, and unto God would I commit my cause” (Job 5.8). Both Eliphaz and Mrs. Turpin continue with their foolish assessments until they are publically humiliated. The former is upbraided by the Lord: "the Lord said to Eliphaz the Temanite, My wrath is kindled against thee, and against thy two friends: for ye have not spoken of me the thing that is right, as my servant Job hath" (Job 42.7). The latter is by rebuked Mary Grace: "The girl raised her head. Her gaze locked with Mrs. Turpin's. 'Go back to hell where you came 
from, you old wart hog,' she whispered. Her voice was low but clear. Her eyes burned for a moment as if she saw with pleasure that her message had struck its target. Mrs. Turpin sank back in her chair" (646). Truly, only some sort of striking fall can inspire introspection in Eliphaz and Mrs. Ruby Turpin.

The horrid image of being an old wart hog from hell is indeed the catalyst for Mrs. Turpin's repentance, yet having this overwhelming thought does not liken her unto Job. Mrs. Turpin's anguish in being unable to reconcile both the futility and efficacy of good works does. Job, as well as Mrs. Turpin, cannot comprehend his tragic circumstance. He reasons, "I was not in safety, neither had I rest, neither was I quiet; yet trouble came" (Job 3.26). Job's lamentation is all too plain to Southern readers. Biblically, what commonly precedes trouble or strife is some degree of sin or "backsliding indulgence, but in Job's case, it came upon him in the midst of alert, watchfulness-for his own family as well as his own moral condition” (Ruckman 46). Job is indeed a virtuous, God-fearing person. He is careful to maintain good works, and in a balanced world, where one actually reaps what he/she sows, Job's complaint is legitimate. Just the same, Mrs. Turpin clings to her religious works, and she cannot imagine how "a respectable, hard-working, [and] church-going woman" (648), such as herself, can at the same time be a wart hog from hell. From their ensuing anxiety, both Job and Mrs. Turpin develop the selfsame desire, that is, "that the Almighty would answer [them]" (Job 31.35).

Mrs. Turpin loudly contends with the Lord, and the resulting tension pushes her toward her ultimate revelation. She shouts, "Go on...call me a hog! Call me a hog again. From hell. Call me a wart hog from hell. Put that bottom rail on top. There'll still be a top 
and bottom!" (653). She is still hindered here by her binary, and thus faulty, perspective, yet in spite of herself, Mrs. Turpin hears from the Lord. Her reply to God though is insolent, for she asks, "Who do you think you are? (653; emphasis added). These very words finalize her tirade, and their significance is clear: she finally reaches the point where she sees not herself, but the Lord's identity. Only then is she able to comprehend her own deficiency.

Up until this point in her life, Mrs. Turpin has used her skewed standards as the means to interpret her surroundings, and sadly enough, it is most likely her religious environment that has conditioned her to view life with this shallow lens. (There is certainly no indication that her Southern experience, that is, her work "for the church" [652], has helped her to mature beyond this perspective.) But in this unsettling moment, Mrs. Turpin is spiritually quickened: "Then like a monumental statue coming to life, she bent her head slowly and gazed, as if through the very heart of mystery" (653). She suddenly comprehends her need and thus the value of true repentance - not a regretful turning from what she has done in life, but a turning from who or what she is.

Indeed, the spiritual profundity of "Revelation" lies in the similarity of the two protagonists Job and Mrs. Turpin. Mrs. Turpin is converted, as is Mrs. Shortley in "The Displaced Person," but readers can see in "Revelation" more clearly the one condition or prerequisite for entrance into the aforementioned eternal mystery. While Mrs. Turpin contemplates her standing before God, a shocking vision settles in her mind. She sees a procession of sinners who, in spite of their "good order and common sense and respectable behavior" (654), learn "that even their [Southern] virtues were being burned away" (654). Thus, like the Book of Job, "Revelation" may illuminate for readers the 
inadequacy of human virtue, and only a sincere, faithful acknowledgment of this inadequacy allows Mrs. Turpin to receive God's grace. She, like Job, can at last reply, "Behold, I am vile; what shall I answer thee? I will lay mine hand upon my mouth" (Job 40.4). That is to say, Mrs. Turpin's encounter with the Lord has wrought a complete change, and she is consequently revived. Her objective now is to praise the Lord by singing and "shouting hallelujah" (654; emphasis added).

Arguably the most graphic or explicit of Flannery O'Connor's conversion stories is "Parker's Back." It is a short story that builds on the two abovementioned short stories, for it details the totality of the Christian conversion experience in the South—not only the conversion itself but also the difficulties that prevent and, perhaps more importantly, succeed it. Truly, by analyzing the problematic life Obadiah Elihue Parker, the shortcomings of the South as well as contemporary Christianity are, in part, unveiled.

O. E. Parker's life in the Protestant South is a picture of discontent. At the earliest chronological point in the story, Parker is seen as an impulsive, carnal boy who is governed by emotion. He grows up in an environment that is oddly religious; he is baptized at the age of a month, and "his mother was a Methodist" (O'Connor, Collected 662). But the Christian faith obviously does not take root early on because the young Parker has "never...felt the least motion of wonder in himself" (658). It is not until he sees a veritable circus "freak," a man who is completely tattooed, that Parker is "filled with emotion" and notices a subtle interest in his eternal existence (657-658). Parker covets tattoos as a result of this encounter, and he receives his first tattoo soon after. Perhaps the ink on his skin is his way of creating an identity separate from, and antagonistic to, his disingenuous religious environment. The South is certainly sending 
mixed signals to Parker, for although his Methodist mother has him baptized and tries to drag him off to a revival, only to see him flee from her grasp once "he saw the big lighted church," she enables his carnality as well by paying for one of his tattoos (658).

Parker continues to accumulate tattoos while enlisted in the Navy, and each of his arbitrarily-conceived tattoos, whether it is lifeless or colorful, is meant to appease or allay his growing discontentment. These small treasures, however, do little in accomplishing this:

Whenever a decent-sized mirror was available, he would get in front of it and study his overall look. The effect was not of one intricate arabesque of colors but of something haphazard and botched. A huge dissatisfaction would come over him and he would go off and find another tattooist and have another space filled up. The front of Parker was almost completely covered but there were no tattoos on his back. He had no desire for one anywhere he could not readily see it himself. As the space on the front of him for tattoos decreased, his dissatisfaction grew and became general. (659)

Parker wishes to gather in visually as much as he can and trusts only what he can see, so he lives his life both abroad and devoid of religious faith. Notwithstanding Parker's attempts to find happiness (and contentment) via carousing, traveling, and of course acquiring tattoos, the South's influence upon his imagination remains: "In port Parker wandered about comparing the run-down places he was in to Birmingham, Alabama" (659).

Indeed, allowing himself to be tossed and carried about by his varied impulses 
(e.g., having meaningless tattoos, binging on beer, and fighting) is Parker's way of assuaging his now raging dissatisfaction. And although he tries for some time to maintain this riotous manner of living in order to ignore or pacify the "peculiar unease that [initially] settled in him" (658), the now jaded Parker finds himself looking to the region where religious talk is practically a staple to everyday life just to find some sort of comfort or peace of mind. Thus, Parker returns to the South once he is dishonorably discharged from the Navy, for the South presumably stabilizes him. It provides both a moral structure to loathe and a place to find a decent wife.

Present in Parker's post-Navy life is an interesting tension. The rural South often compels a man to consider the deep things of God; however, the carnal behavior of those Southerners who pervert or distort the clear conception of these spiritual principles hinders Parker from understanding and relishing "the simplicity that is in Christ" (2 Cor. 11.3). Parker's future wife, Sarah Ruth, is a fine example of such a Southerner. She is quick to quote portions of Scripture, and she readily mentions Bible doctrines while contending with Parker. However, Sarah Ruth actually hampers Parker's spiritual birth/conversion. That is, she serves to further distort his perspective of Christianity and the Bible; in effect, she leads him toward carnality, not away from it. For example, upon meeting Parker, Sarah Ruth points to the tattoos on his arm, and after giving some consideration as to the appropriate Bible verse, she blurts out, "Vanity of vanities" (660). She is being pharisaical, though, because she regards only his external appearance.

Later, Sarah Ruth argues with Parker after discovering his numerous other tattoos: "At the judgement seat of God, Jesus is going to say to you, 'What you been doing all 
your life besides have pictures drawn all over you?"” (663-664). This claim especially is of interest because the exact phrase "the judgment seat of God" does not exist in the Bible. Sarah Ruth is perhaps conflating "the judgment seat of Christ" (2 Cor. 5.10), where Christians are judged before God the Son, and "the great white throne" judgment (Rev. 20.11), where non-Christians are judged before God the Father. Both judgments indeed have works as their focal point, but salvation is a foregone conclusion for those appearing at the former judgment because good works are not a necessary element for the salvation of Christians. In other words, Sarah Ruth is not distinguishing the old testament, where works are an integral part of salvation, from the new, where one is saved simply by the grace of God.

It is not even clear that Sarah Ruth has an understanding of this vital and most basic Protestant principle, for when she replies to Parker's desire for a kiss and, thus, his brazen parody of salvation, she says, “That ain't being saved" (663; emphasis added). Implicit in Sarah Ruth's retort is a falsehood: by using the present participle verb "being" in this sentence, Sarah Ruth implies that salvation is progressive and conditional on a person's virtue or good works. Again, to be saved under the new testament is to have received the free gift of righteousness by faith (Acts 16.30-31; Eph. 2.8-9; Rom. 4:5). A Christian's salvation then is an event, not a process. It is a type of legal transaction where a free gift is received. It is certainly not quid pro quo.

The religious tension does not stem from just Sarah Ruth though; the entire culture of the South it seems is guilty of obscuring Parker's spiritual inkling or vision. Sarah Ruth's father is "a Straight Gospel preacher" (662), yet it is his daughter who contorts the gospel of the grace of God (Acts 20.24), marries a tattooed heathen, and even 
comes to the conclusion that "churches were idolatrous" (661). Likewise, Sarah Ruth's mother is anything but spiritual or godly: she is not troubled at all by the attention $\mathrm{O}$. E. Parker pays to Sarah Ruth, just "so long as he brought a basket of something with him when he came" (662).

The amalgamation of Christian fanaticism and Southern hypocrisy was once something that Parker dissociated and quite literally ran from, but at this point in his life he contemplates participating in it, if for no other reason than "to bring Sarah Ruth to heel" (665). In truth, Parker is perplexed equally by his social environment and his own thoughts, and he concludes that a religious tattoo on his back will be the appropriate way to satisfy both his "Christian" wife and his increasing anxiety. Some readers mark this religious tattoo as Parker's metaphorical step of faith. For example, critic David R. Mayer says that "the tattoo of a face of Christ brings about a change in...Parker and he realizes his potentiality as a person created and graced by God" (119). However, his new tattoo is actually a result of his acceptance of God's grace. Parker's conversion, to wit, his crucial step of faith, actually occurs while he is attempting to circle an old tree in his boss' tractor and hay baler:

As he circled the field his mind was on a suitable design for his back. The sun, the size of a golf ball, began to switch regularly from in front to behind him, but he appeared to see it both places as if he had eyes in the back of his head. All at once he saw the tree reaching out to grasp him. A ferocious thud propelled him into the air, and he heard himself yelling in an unbelievably loud voice, 'GOD ABOVE!'” (665)

Parker's tattoo of Christ actually resembles what is termed "believer's baptism," an event 
popular in many Baptist churches throughout the South. Both Parker's religious tattoo and a convert's baptism in water are simply outward showings of an inward acceptance. They are both figures of a spiritual birth. Parker's true acceptance of God/faith is evident, for after the crash, he "did not allow himself to think on the way to the city [to obtain his tattoo of Christ]. He only knew that there had been a great change in his life, a leap forward into a worse unknown, and that there was nothing he could do about it. It was for all intents accomplished" (666).

Prior to his conversion to Christianity, Parker was always one to hide his Biblical name if he could, preferring to be called either O. E. or Parker. He was always reluctant to identify himself with his Southern background. And now even after his conversion, Parker is still finding it difficult to sincerely embrace his identity. His tattoo artist asks Parker, "One thing I want to know....why do you want this on you? Have you gone and got religion? Are you saved?" (669). Parker denies his salvation, but his words carry no conviction: they "seemed to leave his mouth like wraiths and to evaporate at once as if he had never uttered them" (669). Shortly after the completion of his tattoo, Parker denies his identity again in the local pool hall. He is asked by someone in the raucous crowd if the new tattoo means that he is now "witnessing for Jesus," but Parker dissembles and says that the tattoo is meant just for laughs (671-672).

It is not until Parker goes home to Sarah Ruth that he openly acknowledges his new identity, for in Sarah Ruth, Parker expects to find joy and comfort from someone who is likeminded. Sarah Ruth first questions who it is at the door, and Parker whispers to her his Biblical name, Obadiah Elihue. As a result, Parker "all at once...felt the light pouring through him, turning his spider web soul into a perfect arabesque of colors, a 
garden of trees and birds and beasts" (673). Although he now finds his long sought-after peace of mind, his joy and temperance are fleeting, for what he encounters in Sarah Ruth as he stands and shows her the tattoo of Christ on his back is not a kindred spirit but an insensitive, obtuse person in the flesh. Parker is taken aback while she exclaims, "Idolatry! Enflaming yourself with idols under every green tree! I can put up with lies and vanity but I don't want no idolator in this house!" (674).

The final image readers are chronologically left with, which is presented in the beginning of the text, is one of Parker "puzzled and ashamed" (655). His social environment is practically the cause of his anguish, despite what the Christians in his town may purport to be. And though as a result of his salvation he can now make sense of those around him, especially Sarah Ruth, he cannot reconcile his new spiritual identity with the callousness of his local community. Perhaps he is not even supposed to do this, but be that as it may, Parker has not yet realized that being a Christian, that is, having a spiritual identity "in Christ," does not absolutely mean that one will be at ease or find an inclusive community to exist in. He remains an outsider, but now he is an outsider to not only his local religious community but to the areligious as well. "Parker's Back" comes full circle because the hero indeed reaches an understanding of his eternal existence, an understanding that was first contemplated when Parker saw the tattooed man at the local fair. However, the cost is that Parker essentially becomes the tattooed "freak," for Parker's marred body is a disorderly conglomeration of pictures and colors.

O'Connor's "The Lame Shall Enter First" is certainly not a glorious Christian conversion story. It is, though, a short story that details a type of conversion to humanism as well as a convert's failed attempt to proselytize others. Sheppard, the hero of this story, 
sort of picks up where O. E. Parker left off: he is a devout witness who is, in effect, working out his own "salvation" in the South.

Sheppard is seemingly quite complicated. He is a zealous father who attempts to rectify social wrongdoings, yet in the process he either misreads motives or fails to acknowledge them. The deeper issues inside others - the hidden issues of the heart, as it were-are not something Sheppard sees or perhaps even cares to see. The tragic effect is that he not only fails in inspiring Rufus Johnson, a deviant youth assigned to a local reformatory, but in nurturing and protecting his only son Norton as well.

The story immediately opens with Sheppard assessing Norton. He presumes to know what he, in fact, cannot know about his son: “The boy's future was written in his face. He would be a banker. No, worse. He would operate a small loan company. All he wanted for the child was that he be good and unselfish and neither seemed likely" (O’Connor, Collected 595). What makes this assessment all the more foolish-and tragic - is that Sheppard deems himself some sort of director or teacher of wayward youth, yet he ignores why his own son is listless and grieving, or at the least he does not give proper consideration to his son's deeper psychological needs. Outwardly, Sheppard works to build up others. His goal in theory is to save the less fortunate through good deeds and selfless acts of counseling; however, in practice Sheppard focuses on himself. While upbraiding Norton for essentially mourning the death of his mother, Sheppard says, “Don't you think I'm lonely without her too... Don't you think I miss her at all? I do, but I'm not sitting around moping. I'm busy helping other people" (597-598). Sheppard's selfishness, as he reproves his son and sits miserably "like a man lashed by some elemental force of nature" (597), is evident to readers. 
Sheppard continues to objectify Norton, deeming his son's state to be irreparable. Sheppard even comes to detest his son's supposedly innate character: he thinks to himself that when his wife was alive, "they had often eaten outside, even breakfast, on the grass. He had never noticed then that the child was selfish" (596; emphasis added).

Rufus Johnson, Sheppard observes, is not so, for he sees in the 14-year-old Johnson a potential for growth and virtue that he simply does not see in his 10-year-old son. Sheppard the do-gooder, thus, turns his attention to Rufus Johnson. He learns that Johnson grew up in a home that was destitute of modern values and ethics, for Rufus "was raised by his [religious] grandfather in a shack without water or electricity and the old man beat him every day" (596). Yet despite this obvious deficiency, Johnson possesses an extraordinary gift, which Sheppard knew to be so "from the time the boy had limped in for his first interview" (599).

Clearly it is Sheppard's fixation on certain modern principles that creates his faulty outlook. As a volunteer counselor at the local reformatory, Sheppard studies Johnson's history and sees that Johnson has a recorded I. Q. of 140. He uses this information to conclude that "Johnson was worth any amount of effort" (599), for where "there was [natural] intelligence anything was possible" (601). Sheppard discovers as well that Johnson did not have the advantages of a modern home. Sheppard's vision of the ideal home is detailed in his admonition to Norton when he says, "You have... good home. You've never been taught anything but the truth. Your daddy gives you everything you need and want. You don't have a grandfather who beats you" (597). Interestingly, Sheppard is as parochial or narrow-minded here as Johnson's Christian grandfather, whom Sheppard condemns. Indeed, Sheppard operates on as much faith and conviction 
as Johnson's grandfather when he reportedly goes "with a remnant...to bury Bibles in a cave" in preparation for some sort of apocalyptic salvation (607). The difference is that instead of Biblical doctrines, which Sheppard loathes, humanism and modern psychology are Sheppard's guiding hope.

Sheppard's disgust of Christianity and the Bible is, in part, revealed to readers during Johnson's initial interview. Sheppard resents Johnson's answer that Satan is the cause of his lawless behavior:

He felt a momentary dull of despair as if he were faced with some elemental warping of nature that had happened too long ago to be corrected now. This boy's questions about life had been answered by signs nailed on pine trees: DOES SATAN HAVE YOU IN HIS POWER? REPENT OR BURN HELL. JESUS SAVES. He would know the Bible with or without reading it. His despair gave way to outrage. 'Rubbish!' he snorted. 'We're living in the space age! You're too smart to give me an answer like that.' (601)

Later, Sheppard flatly rebukes Johnson for using the Bible to support his conclusion that apart from believing in Jesus Christ, space exploration will do no good: "That book is something for you to hide behind...It's for cowards, people who are afraid to stand on their own feet and figure things out for themselves" (627).

However, despite Sheppard's obvious aversion to the Holy Bible as well as oldtime Southern principles, it would be too simple to conclude that he is irreligious or devoid of Christian principles. Sheppard is certainly aware of a number of Biblical doctrines, and his social setting, to some degree, must be influential on his thought 
process. After all, he asks God for strength once, albeit "under his breath" (626).

Flannery O'Connor's short stories are indeed replete with characters who, although they are not exactly Protestant in their outlook, turn to Christian or faith-based principles in a time of decision. Their peculiar acts certainly add profoundness and intrigue to O'Connor's fiction. For instance, Mrs. McIntyre in "The Displaced Person" shows little interest in organized religion, yet she uses a room in her house as a sort of make-shift chapel. This rather sacred room has her dead husband's safe "set like a tabernacle in the center of it," and she often derives strength by sitting motionless before it "for ten or fifteen minutes" (312). Moreover, her outrage at Mr. Guizac's attempt to have his Polish cousin marry Sulk, her black farmhand, is telling. She simply will not allow a black male to marry a white female under her watch, and her following statement about Mr. Guizac signifies her belief in the controversial Biblical doctrine of racial segregation (Gen. 9:17-27; Acts 17.26): "I cannot understand how a man who calls himself a Christian...could bring a poor innocent girl over here and marry her to something like that. I cannot understand it" (314; emphasis added). Mrs. McIntyre is at the very least indirectly influenced by Southern religious principles even though she protests, "I'm not theological. I'm practical" (316).

Similarly, Chancey Shortley is shaped by the South and thereby uses Biblical principles to justify his cause. (Unlike Mrs. McIntyre, however, his religious sentiment is feigned.) Compelled by revenge, Mr. Shortley believes that his sole responsibility after his wife's death is to "wait on the hand of God to strike, but he knew one thing: he was not going to wait with his mouth shut" (323). He thus sets out to hasten the fall of Mr. Guizac: "he began to complain and to state his side of the case to every person he saw, 
black or white. He complained in the grocery store and at the courthouse and on the street corner and directly to Mrs. McIntyre herself, for there was nothing underhanded about him" (323). His attitude and actions here parallel the behavior of his late wife, and he finds that he has the same gift that she had, that is, "the power of making other people see his logic" (323). Mr. Shortley subsequently defends himself to Mrs. McIntyre by boasting of his war heroics, and in doing so, he likens himself to Jesus Christ. In a claim that is both laughable and blasphemous, he first reiterates the Constitutional maxim of equality by stating that all "men was created equal" (323), and he then adds, "I risked my life and limb to prove it. Gone over there and fought and bled and died and come back on over here and find out who's got my job - just exactly who I been fighting" (323; emphasis added).

This type of distorted and even feigned religiosity is a staple to Flannery O'Connor's fiction. Sheppard, then, can represent a sort of departure or defection from O.E. Parker's final stage as a spirit-filled (but dejected) Christian. Sheppard in fact is knowledgeable, and he zealously works to save Rufus Johnson, albeit through "psychology and the dodges of the human mind to astronomy and the space capsules" (601). He cares for children and thus considers himself to be "a good man... [with] nothing to reproach himself with" (626). However, because he is unable to address the inner-needs of his flock (i.e., he can only shape or reform its exterior), Sheppard amounts to a Christian apostate, a perverted figure of Christ. Rufus Johnson certainly intimates this when he considers Sheppard and says, "He thinks he's Jesus Christ" (609).

Nevertheless, the terminus of "The Lame Shall Enter First" provides to Protestant readers a dangerous vision of modern psychology/education. It marks, as well, the tragic 
result of Christian apostasy in the South, or what may happen when good (social) works are coveted and not viewed as simply the accompaniment to spiritual living. This short story, too, ends with an epiphany: Sheppard is repulsed by and estranged from his former self, and graciously receives "a transfusion of life" (632). He thereby comes to understand that the secular principles he once so ardently believed in and advocated to others are carnal and thus ineffectual. Sheppard has acquired or perhaps reclaimed an eternal perspective, but at a greater cost than even Parker's. That is, Sheppard's rebirth cost him his son's life. Upon seeing Norton's lifeless body hanging from a beam in the attic, Sheppard reels back in horror, and the heartrending image of his son's corpse gives shape to the Apostle Paul's warning that "to be carnally minded is death" (Rom. 8.7).

These four short stories, grouped in this successive order, present a rather intricate picture of the Protestant South. Certainly other conversions, religious or otherwise, can be found in Flannery O'Connor's short stories, and perhaps those conversions merit analysis as well. But none reveal the manifold psychological aspects of the individual convert's struggle with faith as well as with his/her social environment like these four short stories. That is to say, when strung together these four stories poignantly reveal the magnitude of a Christian's step of faith and still further the tragic consequence of forsaking "the fellowship of the mystery" (Eph. 3.9). 
Chapter IV: Answering the Call

In Flannery O'Connor's longest and most complex work, The Violent Bear It Away, Francis Marion Tarwater's coming-of-age is the focal point. He is a troubled youth who is beset on all sides with tension and strife, which stem from the influences of his uncles Mason Tarwater and George Rayber. The former is a rabid and seemingly oldfashioned Southerner who raises Francis Tarwater with the Bible as a primary guide - he likens "their situation to that of Elijah and Elisha" (O'Connor, Collected 356). The latter is a self-professed escapee of this rather Southern upbringing, yet one who is still cumbered by the markings of an exclusive faith - he is "in principle and practice, the Atheist of Protestant descent" (O'Connor, Habit 141). Francis Tarwater matures between this jarring confluence of personalities, as well as amid a variety of strange carnal pressures. Thus, he is much like the previous characters who arrive at a calming faith "in Christ," but only after striving greatly within their respective environments. What is significant about young Tarwater though and what ultimately distinguishes him from these characters, "children who meet theological truths beyond their understanding" (O'Connor, Habit 89), is his resolve to not just do according to the will of God, but to indentify himself with the will of God.

Francis Tarwater is reared on a secluded estate named Powderhead, and from the outset of the novel, he is charged with a commission by his caregiver. Mason Tarwater tells him that his first act as a minister of the Lord will be to baptize and essentially save his dim-witted cousin Bishop. This commission, however, is something young Tarwater initially resists. He has a more significant calling in mind: "he thought of Moses who struck water from a rock, Joshua who made the sun stand still, of Daniel who stared down 
lions in the pit" (O’Connor, Collected 335). Indeed, his portentous call to the ministry together with the uncertain decisions that he must make is central to this novel. Old Tarwater, who professes to be quite familiar with Christian ministry, ominously warns, "It's no part of your job to think for the Lord...Judgment may rack your bones" (335). Young Tarwater faces a battle of wills, and at stake is his role as a Christian. To be sure, his struggle is ontological in nature. Emmanuel Lévinas, a philosopher and Talmudic commentator, argues in his preface to Totality and Infinity "that it is of the highest importance to know whether we are not duped by morality" (21). For Lévinas, ethical concerns and decisions hinge on the encounter with the "Other." This Other, which may refer to either a person or principle outside of one's being, helps to define or make up one's role/identity. And since language is differential or, in other words, culturally contingent-in the case of Tarwater it is largely constructed by Southern religious values-Tarwater's existence can never be fully "grasp[ed] as a finish object." That is, his identity as a Christian minister is problematic, for it is only understood in part, and that by his "practical bound-upness with the world" around him (Eagleton 54).

Lévinas' theory is significant, for although Francis Tarwater's vocation is shaped and practically enforced by his Southern caregiver, Tarwater must discern his prophetic calling for himself. That is, if his ministry is to be effectual, Tarwater must be fully persuaded in his own mind. In addition, as a Christian Tarwater is commanded to prove all things (I Th. 5.21). The extreme violence that succeeds Tarwater's call to minister highlights his conflicting interests and illustrates the complex nature of his choice. Lévinas further writes,

Harsh reality...is produced as the pure experience of pure being. The 
ontological event that takes form in this black light is a casting into movement of beings hitherto anchored in their identity, a mobilization of absolutes, by an objective order from which there is no escape. The trial by force is the test of the real. But violence does not consist so much in injuring and annihilating persons as in interrupting their continuity, making them play roles in which they no longer recognize themselves, making them betray not only commitments but their own substance, making them carry out actions that will destroy every possibility for [selfwilled] action...War does not manifest exteriority and the other as other; it destroys the identity of the same. (21)

The harsh war within young Tarwater culminates in a Southern "preacher's kid" who has examined his calling and has thereafter rid himself of ambition. His will is no longer relevant, for he understands at last that he is not his own and "that nothing on earth would fill him" (O’Connor, Collected 478). His once romantic conception of a prophet's ministry is resolved into a renunciation of identity. And just as it is regularly played out in one form or another in militant churches across the Protestant South, Tarwater yields to - what he believes to be - "the fate that awaited him" (479), to wit, his preordained responsibility to preach and in effect save others. The image of young Tarwater in the final scene of The Violent Bear It Away is both pointed and lasting. With "singed eyes, black in their deep sockets," a hungry Tarwater walks steadfastly toward his objective, even at midnight, for he is now resolved to shepherd "the dark city, where the children of God lay sleeping" (479).

Francis Marion Tarwater is a product of Flannery O'Connor's unique blend of 
distortion and Biblical truth. Moreover, Tarwater is indicative of O'Connor's Southern literature as a whole, or as the author puts it, "the peculiar crossroads where time and place and eternity somehow meet" (Collected 848). His dark life is, thus, best understood by a Protestant reader or someone for whom time and place and eternity matter. His experiences as a prophet-in-training indeed present a host of hermeneutical problems, and perhaps the reader's chief task is determining where the line between distortion and Christian truth exists.

At Powderhead, young Tarwater is positioned in a bizarre setting. Ostensibly, his upbringing is sound and stable, for it is anchored in the word of God. Old Mason Tarwater is his great-uncle — or at least "said he was" (O'Connor, Collected 331) — and the old man assumes the responsibility of caring for Tarwater. He raises the child by exclusively teaching "him Figures, Reading, Writing, and History beginning with Adam expelled from the Garden and going on down through the presidents to Herbert Hoover and on in speculation toward the Second Coming and the Day of Judgment" (331). In the old man's mind, Francis Tarwater is privileged because he has been rescued from his former connections, even Rayber the schoolteacher, whose modern ideas on education are antithetical to "the Christian way" and who wilily employs "questions that meant more than one thing" (331).

All of what Tarwater is taught, however, comes via the old man's shifting and oftrepeated recollections. He is not provided constancy, nor the so-called "hard facts of serving the Lord" (332), under the old man's tutelage as is supposed. Even Francis Tarwater's family history is taught to him through the filter of Mason's perspective, and what is more, the old man's wavering recollections do "not always move at the same rate 
of speed through every point in his story." He will often speed over the more important details of his story and even become "so heavy...that he would stop telling the story to Tarwater, stop and stare in front of him as if he were looking into a pit which had opened up before his feet" (334). Poor Tarwater simply has no antecedent to cleave to because, for him, truth and error hinge on the arbitrary impulses of his great uncle. The ultimate effect of this convoluted upbringing is that Tarwater is left unsure of himself and his calling. There are times when "Tarwater knew that when he was called, he would say, 'Here I am, Lord, ready!' At other times when there was no fire in his uncle's eye and he spoke only of the sweat and stink of the cross, of being born again to die, and of spending eternity eating the bread of life, the boy would let his mind wander off to other subjects" (334).

Francis Tarwater's life is abruptly altered when his caregiver dies. At the age of just 14 , he has the awful responsibility of having to bury his great-uncle in a prescribed manner, but even more disconcerting is the prospect of having to set out in the ministry of the gospel alone. He is his great-uncle's workmanship of course, and he has seemingly been prepared for this moment, but with now having to discern and make sense of his calling without his great-uncle's heady instructions, Tarwater is affected by thoughts that are as odd and conflicting as is his familial background. Previously, the uncertainties that existed in Tarwater's mind were assuaged by his great-uncle's pious phrases and Biblical admonitions. Old Tarwater conditions him and affirms, "You were born into bondage and baptized into freedom, into the death of the Lord, into the death of the Lord Jesus Christ" (342). Elsewhere, Mason Tarwater uses a grim precedent from the Bible to warn the young boy of the danger that the outside world and specifically his uncle Rayber 
represent: "Remember the Lord's lion set in the path of the false prophet!" (344).

Because he is a Bible-believer at heart, Francis Tarwater is quieted and managed by this terse reproof, which points to an Old Testament prophet's cause of death: a naïve prophet heeds a falsehood, disobeys in effect "the mouth of the Lord, and...the commandment which the Lord...commanded" (I Kin. 13.21), and suffers an untimely death as a result. However, Tarwater is now alone amid the grave digging, with only his memories to guide him. So as a means of finding assurance and direction, he speaks aloud to himself. He initially says, "The dead are poor" (345), and this simple speech act quickly evolves into an intense dialogue between Tarwater and the voice of the stranger.

At first consoling but then argumentative and obstinate, this strange inner-voice appears to Tarwater as the voice of logic and reason. It assures Tarwater of his autonomy as well as the old man's lunacy, and its plain purpose is to dissuade Tarwater from entering the ministry. The stranger commences by challenging the religious principles that Tarwater has been taught. While Tarwater takes a respite from the digging, the stranger says to him: "The dead are a heap more trouble than the living...That schoolteacher [George Rayber] wouldn't consider for a minute that on the last day all the bodies marked by crosses will be gathered. In the rest of the world they do things different than what you been taught" (345). The stranger is positing here that societal norms and customs are intrinsically worthless. That is to say, Tarwater's beliefs are a mere construction of relative ideas, no more valuable than other religious systems found throughout the world. Tarwater's verbal response to this argument certainly reveals or demonstrates both his naïveté and just how limited his life experience is, for he simply says, "I been there once" (345). Nevertheless, it is Tarwater's thoughts that immediately 
follow that are truly revealing, for his life-altering objective is contained therein.

Tarwater thinks to the one time he left Powderhead to visit the neighboring city. It is there that he meets not only his uncle Rayber and the cousin whom he presumably must baptize, but his ultimate purpose as well. The inhabitants of this city instantly and forever shape Tarwater: upon witnessing them, Tarwater develops a spiritual burden for "the ducked heads, the muttered words, the hastening away. He saw in a burst of light that these people were hastening away from the Lord God Almighty" (346). Though Mason Tarwater can be attributed with creating in Francis the will to prophesy, it is the people of this neighboring city who provide an actual focus to Tarwater's ministry. They give the young prophet a body to target.

The crafty stranger, who is becoming friendlier and more intimate with Tarwater as time passes, understands Tarwater's intentions and stops at nothing to prevent him from addressing his deep-seated burden. They are digging the grave together now - at least this is so in Tarwater's mind - and the voice of the stranger continues by questioning his calling. The stranger jeers, "Look at the big prophet...Lemme hear you prophesy something. The truth is the Lord ain't studying about you. You ain't entered His Head...Anybody that's a prophet has got to have somebody to prophesy to. Unless you're just going to baptize that dim-witted child, he added in a tone of high sarcasm" (353354). He also ridicules old Tarwater and, in turn, the very office of a prophet: "[Mason Tarwater] was always admitting somebody was an ass or a whore. That's all a prophet is good for - to admit somebody else is an ass or a whore" (355). Tarwater does not respond to these claims because he actually comes to appreciate the stranger. That is, he finds value in or believes much of what the stranger posits about his religious training at 
Powderhead. The two truly understand each other, and despite the stranger's contentious words, a sort of shared yet confounding friendship emerges. The result is a very disturbed boy, whom literary critic Ted R. Spivey contends is “O'Connor's deepest and most difficult visionary insight" (138). This is so particularly because of the bizarre dialogue which fuels this friendship. Tarwater's discourse with the stranger is one-half a recollection of his life at Powderhead and one-half a confirmation of his own doubts and fears. What the argumentative stranger represents for Tarwater, apparently, is a sort of defense mechanism; indeed, the voice of the stranger is born of necessity.

Tarwater has a very problematic childhood. He is sheltered from outside influences at Powderhead so that his only tangible example of a Christian is his greatuncle, who readily boasts of his own work in the ministry. Indeed, Mason Tarwater often likens himself unto the valiant, faithful doers of the Bible (e.g., Moses, Elijah, Ezekiel, and John the Baptist), and he even wears or puts on the image of a Biblical prophet in rather dramatic fashion:

At such times he would wander into the woods and leave Tarwater alone in the clearing, occasionally for days, while he thrashed out his peace with the Lord, and when he returned, bedraggled and hungry, he would look the way the boy thought a prophet ought to look. He would look as if he had been wrestling a wildcat, as if his head were still full of the visions he had seen in its eyes, wheels of light and strange beasts with giant wings of fire and four heads turned to the four points of the universe. (334)

The old man's motives, even his sanity, are debated among critics. What is certain though is that Mason's collective actions bewilder the young boy. Tarwater is unable to reconcile 
what he is taught by his great-uncle with what he actually sees in him.

For instance, old Tarwater brings Francis out of the city to homeschool him and to raise him "according to [Christian] principle" (358), and he often reiterates to the young boy that a prophet's reward is "the Lord Jesus Himself, the bread of life" (369). He in effect adjures Tarwater to walk faithfully by setting his affection on things above and not on earthly things (Col. 3.2). However, Mason Tarwater violates his own admonition by making homemade whiskey and having “a weakness for it himself. When he couldn't stand the Lord one instant longer, he got drunk, prophet or no prophet" (358). Young Tarwater is not only a witness to this, but he is even compelled to participate in the making of the homemade liquor by toting "mash to the still" (358).

What is more, while on the aforementioned visit to the neighboring city, Tarwater is disconcerted by his great-uncle's indifference. The young prophet-in-training is of course awakened by the great spiritual need before him, recalling Biblical precedents where prophets would vehemently preach in the midst of the city. His great-uncle, though, is "no more concerned with it all than a bear in the woods" (346). Young Tarwater marvels at his mentor's lack of concern and questions his motive, but the old man dismisses him and tells him to mind his own calling and mission. Mason concludes, “And I know what times I'm called and what times I ain't” (347).

Young Tarwater processes what he hears and sees from his great-uncle and has little choice but to adapt. His behavior and thoughts are thus conditioned by the old man's duplicitous actions, and the strange friend whom Tarwater converses with is the product. It is perhaps natural to connect Tarwater's friend with "the voice of the devil urging him to deny a belief in the divine" (Spivey 138), especially with the opposing presence of the 
devil being such a prominent image in popular culture. This interpretation logically springs from the notion that Tarwater is a disobedient soul who is trying to escape his ministerial calling in order to enjoy the fruits of sin. It neglects, however, the Pauline doctrine that each born-again Christian is in type a schizophrenic, to wit, one who freely chooses to obey either his carnal nature, which is a construct of its cultural environment, or his imputed spiritual nature, which solely delights "in the law of God after the inward man" (Rom. 7.22). Tarwater is a born-again Christian. His psyche is therefore a dichotomy between faith and doubt. The areligious stranger is, to be exact, Tarwater's alter ego, for Tarwater feels that he is "only just now meeting himself, as if as long as his uncle had lived, he had been deprived of his own acquaintance" (O'Connor, Collected 352). He creates this alternate identity, in short, as a means to interpret the mixed messages that he has received from his mentor.

This device or mechanism soon proves to be ineffectual though, for the merging of the stranger's logic and Tarwater's Christian beliefs heightens Tarwater's anxiety beyond what he can control or process. On the one hand, Tarwater's mind readily recalls Biblical precedents because he knows the complete "history of the world, beginning with Adam" (366); on the other hand, the stranger persuades Tarwater to abandon his faith, contending that Tarwater's will alone determines the truth: "No no no, the stranger said, there ain't no such thing as a devil. I can tell you that from my own self-experience. I know that for a fact. It ain't Jesus or the devil. It's Jesus or you" (354). This dichotomy is simply too much for Tarwater to take in, so he leaves off burying his great-uncle and flees Powderhead, along with the voice of the stranger, in a numbing act of violence. $\mathrm{He}$ first drinks himself into a stupor and then sets small fires under his great-uncle's house 
until the property is completely ablaze. His goal with this destructive act is to rid himself of his conflated thoughts, in effect to know whom or what he should serve. He tells himself, "Nobody can do both of two things without straining themselves. You can do one thing or you can do the opposite" (354).

Nevertheless, despite Tarwater's numerous misgivings about his great-uncle's teachings, he finds that being completely rid of the Biblical principles that have been ingrained in his heart and mind is impossible. His very senses are exercised to use the Scriptures as a means to discern good and evil. Thus, the imagery of the Bible continues to surface, for after Tarwater exits Powderhead and glances over his shoulder to see the now raging fire, his mind is drawn to a Biblical similitude. Tarwater hears the fire behind him and likens the sound of it to a "whirling chariot" moving up through the dark night (361). He is recalling Elisha's own dramatic vision as his mentor Elijah is raptured in a fiery chariot "by a whirlwind into heaven" (2 Kin. 2.11).

Tarwater's anguished mind is not the only result of this conflation of variant ideas, however. The reader is left unsettled and irresolute, too, because it is unclear as to whether certain of Tarwater's experiences are real or imaginary. Indeed, the line between reality and imagination is blurred at times. Immediately after leaving Powderhead, for example, Tarwater has what seems to be a very surreal experience while hitching a ride from a copper flue salesman. Just like the stranger before him, this traveling salesman, Meeks, is intent on giving young Tarwater advice, only the salesman's advice is not for Tarwater to abandon his faith-based convictions, but to love others while finding his own place in the world: "love was the only policy that worked $95 \%$ of the time" (O'Connor, Collected 362). Tarwater listens to the salesman for an indefinite time and then blurts out, 
"You don't owe the dead anything" (362). Tarwater hears a response: "And that's the way it ought to be in this world—nobody owing nobody nothing" (362). However, it is uncertain whether this response comes from Meeks or the aforementioned stranger. The ambiguity in the text here points to both the obscurity of Tarwater's mind and his wavering intentions. He is truly halt between two equally-influential forces, that is, his fleshly will and his spiritual mind, and perhaps the only thing a reader can be sure of at this moment is that Tarwater's next impulsive act is imminent. He is traveling to his uncle Rayber's, and after hearing — but not actually listening to — the reproof of the salesman, he mutters in a rather ominous and premonitory fashion that he was asleep and is "just now waking up" (363).

After cogitating for quite some time about his family history, Tarwater finally reaches Rayber's home, but before leaving Meeks' presence, Tarwater hints at his motive for seeking his remaining family members. Meeks first asks Tarwater what line of work he wishes to get into, and Tarwater responds, "I know everything but the machines...My great-uncle learnt me everything but first I have to find out how much of it is true" (380). Meeks contends, "You ain't sure about what all this great-uncle of yours told you...You figure he might have got aholt of some misinformation" (381). Tarwater tells him that he will indeed find out the truth and that his initial desire is to "wait and see what happens," but, he adds presciently, if nothing does happen, "I'll make it happen...I can act" (381).

Tarwater's conversation here is revealing and in some respects quite simple, but it can be overlooked by many readers. Tarwater is having a phenomenological moment, as it were. In leaving Powderhead for the city, he is exploring his possibilities and, in turn, his actual self by anticipating death. Philosopher Martin Heidegger, who explores in his 
monumental work Being and Time issues related to death and the temporality of our existence, writes,

Only the anticipation of death drives every chance and 'preliminary' possibility out. Only being free for death gives Da-sein [i.e., Heidegger's term of existence or being] its absolute goal and knocks existence into finitude. The finitude of existence thus seized upon tears one back out of endless multiplicity of possibilities offering themselves nearest by-those of comfort, shirking and taking things easy_and brings Da-sein to the simplicity of its fate. This is how we designate the primordial occurrence of Da-sein that lies in authentic resoluteness in which it hands itself down to itself, free for death, in a possibility that is inherited and yet has chosen.

The connection to Tarwater's quandary is evident: Tarwater cannot have a true or authentic existence unless he comes to terms with his temporality, which is according to author William Cooney "a uniquely human awareness that a human being is a finite, historical, and temporal being. The awareness of death is a central beginning for understanding this temporality." Put in a Christian framework, Tarwater's vitality is contingent upon his act of mortifying the deeds of the flesh. This unique choice between a Christian's carnal impulses and spiritual betterment is explicated by the apostle Paul in his epistle to the local church in Colosse. Paul commands, "Mortify therefore your members which are upon the earth; fornication, uncleanness, inordinate affection, evil concupiscence, and covetousness, which is idolatry" (Col. 3.5).

Indeed, Tarwater represents the perfect dichotomy between the tar of death/sin 
and the water of life, but his wish is not necessarily "to throw off the life power within himself in order to enjoy his own desires and pleasures" (Spivey 138), as one literary critic proposes. His struggle is in determining or proving his ministerial role. That is to say, his grotesque experiences are not figurative, ironic, or allegorical. They are, rather, indicative of a quite prominent occurrence in Protestant Christianity. Although exaggerated and distorted, his is an internal struggle with reconciling his present opportunities with the prior knowledge he has gleaned as a prophet-in-training, and in order to have an authentic existence - to be certain of both whom and how he is to serve-Tarwater must in effect meet death, whether it is death to self or the death of others.

Rayber welcomes Tarwater, for he sees the young boy as a sort of reclamation project, in part, because Rayber too has been deeply affected by the actions of Mason Tarwater. George Rayber in many ways sees himself in the young boy, so he thinks who better than I to reconstruct the fallen or distorted image of young Tarwater. He first hears of how the old man has died and then says to his nephew, "He lived a long and useless life and he did you a great injustice. It's a blessing he's dead at last. All that can be changed now. Now you belong to someone who can help you and understand you...It's not too late for me to make a man of you" (O’Connor, Collected 388). His intent is to stimulate Tarwater through a wide range of cultural perspectives, including books, movies, art galleries, and foods, and thereby show him that the guilt that he must be feeling is just a mental construct, an unfortunate consequence of being "held in bondage by his great-uncle" (396).

Rayber's underlying aspiration though is to prove his own effectuality, that is, to 
justify his own existence, for his previous attempt at psychologically reforming a young man ended in tragic failure. Rayber once met a young man who came to the city to study divinity. A zealous graduate student at the time, Rayber befriended the young man and went about helping "him to discover himself" (392). Subsequently, Rayber orchestrated a relationship between this young man and his sister, and the two soon had a love child together. (The love child who was born is in fact young Tarwater.) But shortly after the death of Rayber's sister — who died in a car accident while pregnant with her love child— the young man regressed, lost any stability that he had garnered through Rayber's efforts, and took his own life. According to Rayber, the young man simply fell "prey to morbid guilt" (392).

Rayber, who in many ways is reminiscent of Sheppard in "The Lame Shall Enter First," is in principle a humanist. He disregards the Biblical doctrines of sin and repentance (which he determines are the cause of the young man's suicide), and he has a pronounced contempt for the atonement of Christ. The latter is expressed, albeit backhandedly, while Rayber argues with young Tarwater about Mason's irrationality and how any attempt to retrieve him from Powderhead would have ended tragically: I didn't have a gun. He would have killed me. He was a mad man. The time when I can do you good is beginning now, and I want to help you. I want to make up for all those years...I want you to understand. He was crazy and if he killed me, you wouldn't have this place to come to now. I'm no fool. I don't believe in senseless sacrifice. A dead man is not going to do you any good, don't you know that?" (395; emphasis added)

In Rayber's mind, anyone who accepts Biblical or faith-based principles is weak-minded, 
lacking in "all dignity" (392), and cursed with "rejecting defiantly one's own obvious good" (442). Yet Rayber, like Sheppard before him, is still affected by certain ideas or beliefs which stem from his Southern background. He is quite cognizant of these affections (he views them as afflictions) and works zealously to dismiss them whenever they surface. However, the end of his efforts is a troubled mind and an inauthentic existence.

Tragically, it is Rayber's son Bishop who is the catalyst for Rayber's anxiety. For it is during the times that Rayber considers his son that he is melancholy and overwrought with an inexplicable feeling that he can only identify as "a love for the child... a touch of the curse that lay in his blood" (401). This feeling Rayber connects to the seed of religion (i.e., the curse) that Mason Tarwater managed to plant within him many years ago - a seed that he has tried so desperately to dislodge. Thus, it is an illogical, impractical emotion that is based on faith and not hard facts:

It was not the kind that could be used for the child's improvement or his own. It was love without reason, love for something futureless, love that appeared to exist only to be itself, imperious and all demanding, the kind that would cause him to make a fool of himself in an instant. And it only began with Bishop. It began with Bishop and then like an avalanche covered everything his reason hated. He always felt with it a rush of longing to have the old man's eyes - insane, fish-coloured, violent with their impossible vision of a world transfigured — turned on him once again. The longing was like an undertow in his blood dragging him backwards to what he knew to be madness. (401) 
The psychological effect that Mason Tarwater has had upon Rayber is certainly profound and lasting, and to combat it, Rayber deviates completely from what he learned during his brief stay at Powderhead. To the dismay of the old man, Rayber becomes a secular schoolteacher, for his recourse is to instruct others in the practical ways of the world and, he tells young Tarwater, "to avoid extremes" (420). For Martin Heidegger, though, a person's being can be entangled and "lost in what it takes care of," and in this "lostness" a person is caught looking away from his own temporality or limitations and thus fleeing his authentic existence, which is "categorized as anticipatory resoluteness" (389). The irony is that it is precisely Rayber's will to avoid extremes, in particular, Mason Tarwater's obsession with "performing the empty rite [of baptism]" (O'Connor, Collected 421), that leads him to attempt an act of violence against his only begotten son.

George Rayber takes Bishop to a beach in order to drown him (not unlike Abraham's intent with his son Isaac), and his objective is to conquer his longstanding psychological pain. Rayber has spent his adult life vacillating between the curse that Mason planted and the secular principles that he now holds to be true, and he reasons that if he can end this vacillation "and with a supreme effort of his will refuse to feel it, he would be a free man" (418). He believes that to "feel nothing [is] peace" (454). However, when confronted with the actual act of murdering his son—specifically Bishop's "face under the water... wrathfully contorted" (418)-Rayber cannot follow through. He fails to meet death, even the death of his son, and thus continues in his afflicted, irresolute condition. What is more, Bishop is rescued from the water by others at the beach, and a picture is immediately taken of Bishop together with Rayber "beside him on his knees, watching with an agonized expression" (419). This photograph appears the next day in 
the local newspaper, and Rayber is all but celebrated by its spurious caption: “OVERJOYED FATHER SEES SON REVIVED”(419).

George Rayber is caught in an interminable state. Subject to a multitude of possibilities, he is unable to muster the resoluteness necessary to have an authentic existence. He thus languishes because he does not have a static objective. At the beach with Bishop, Rayber does come to the brink of freeing himself once and for all of his inexplicable longing, but he lacks the gumption as it were to sacrifice his son- - to be free for death. Rayber instead turns to psychoanalyzing Tarwater as a means of allaying his conflicted thoughts: "It's you the seed fell in...It ain't a thing you can do about it. It fell on bad ground and it fell in deep. With me...it fell on rock and the wind carried it away" (449). However, his judgment here is just as unstable as are his desires, for Rayber soon admits to Tarwater, albeit defensively, "[The seed] fell in us both alike. The difference is that I know it's in me and I keep it under control. I weed it out but you're too blind to know it's in you. You don't even know what makes you do the things you do" (449). Rayber is protective of his outward image and will have those whom he advises esteem him as an uncompromising advocate of secularism, even one who has successfully converted himself from the folly of Southern fundamentalism. His final appeal to Tarwater, though, betrays his sentiments and exposes how muddled his affections actually are. Rayber declares that baptism is a vain act and that the true solution is "being born again the natural way" (451) - through one's own effort and intelligence. He asserts that this method is superior to Mason's, but Rayber is merely equivocating. His words have "a disconnected sound" (451). At length he confesses to Tarwater that "the principle is the same. The way we have to fight it is the same" (451; emphasis added). 
Young Tarwater is not as his uncle Rayber, for Tarwater analyzes his environment and comes to terms with his contradictory impulses. He is also terse. Tarwater adamantly tells Rayber, "It ain't the same...I can pull [the seed] up by the roots, once and for all. I can do something. I ain’t like you" (451). Simply put, Tarwater takes action. He leads Bishop out in a boat and drowns him as well as the memory of Mason Tarwater's words: "baptized into freedom, into the death of the Lord, into the death of the Lord Jesus Christ" (342). Tarwater is subsequently picked up at the side of the road by a truck driver, to whom he says, "The words [of my great-uncle] just come out of themselves but it don't mean nothing. You can't be born again" (458). By drowning Bishop, Tarwater proves to himself that Mason Tarwater's commission to baptize is false. He is now absolved of his great-uncle's dictums and in complete control. Tarwater says, "It's not going to be any destruction or any fire...There are them that can act and them that can't, and them that are hungry and them that ain't. That's all. I can act. And I ain't hungry [for the bread of life]" (459). His aim is thus to return to Powderhead where, he tells the truck driver, no "[prophet's] voice will be uplifted" (458).

Tarwater has suffered a variety of experiences since Mason's death. As a result, he identifies himself as a man "tried in the fire of his refusal, with all the old man's madness smothered for good, so that there was never any chance it would break out in him" (464). However, his past he finds is not something that he can simply disavow. As Tarwater walks toward Powderhead, his thoughts flit between the stretched highway in front of him and his former self, which he now envisions as "a gaunt stranger, the ghost who had been born in the wreck and who had fancied himself destined at that moment to the torture of prophecy" (465). His visceral desire may be "to live his life as he elected it" 
(463), that is, apart from Christian doctrines and precepts, but forsaking the ministry of God is an increasing struggle. Tarwater's anguished mind is the consequence. He tries to assuage his grief by repeating every few steps that he will soon be home, but "he felt the distance between himself and his goal grow longer" (464). Tarwater tries to take a respite by drawing drinking water from a well, but even physical signs point him back to his spiritual mentor: "He drank until he began to feel dizzy. Then he pulled off his hat and thrust his head into the water. As it touched the deeper parts of his face, a shock ran through him, as if he had never been touched by water before. He looked down into a grey clear pool, down and down to where two silent serene eyes were gazing at him" (466).

What Tarwater is finding is integral to his process of becoming a preacher in the South. He tries his great-uncle's commission and thereafter chooses to live carnally instead of mortifying the deeds of his body (Rom. 8.13). However, he was born again under his great-uncle's ministry and hence is a new creature in Christ (2 Cor. 5.17). The Spirit of God that indwells Tarwater, then, will not let him live freely in a state of "endless...possibilities offering themselves nearest by—those of comfort, shirking and taking things easy" (Heidegger 351). Tarwater's anxious moments on his walk to Powderhead thus represent the Lord's chastisement, and they illustrate, at least to Tarwater, that the way of the transgressor is hard (Pro. 13.15). His troubles on the road serve to bring to light as well that "the gifts and calling of God are without repentance" (Rom. 11.29). For although Tarwater is trying to ignore both his relationship with the Lord and his burden to preach in the neighboring city, there ever lies "hidden from his daily sight but present to his inner eye that remained open...the clear grey borders of the 
country he had saved himself from crossing into" (O'Connor, Collected 464).

It is only death to self (i.e., to corporeal desire) or the anticipation of death that will bring life and peace to Tarwater. However, Tarwater does not yet acknowledge this, and in an act of self-gratification and -deception, he accepts a marijuana cigarette and a bottle of whiskey from yet another stranger. Tarwater becomes intoxicated instantly and feels "himself pleasantly deprived of responsibility or of the need for any effort to justify his actions" (471). This new stranger quickly takes advantage of Tarwater's drunken state though and drives him "down into a secluded declivity" (471). It is there that he humbles the unsuspecting Tarwater in what is perhaps the vilest scene in Flannery O'Connor's fiction: while lying unconsciously, Tarwater is sodomized, and he wakes up only to find himself naked, bound, and propped up against a log. Once he fully comes to and realizes what has just occurred, a horrendous cry tears out of him.

There have been several pivotal moments in Tarwater's life (e.g., his epiphany in the neighboring city, his conversation with his strange friend while digging Mason Tarwater's grave, and his violent "baptism" of Bishop), but his rape is chief among them. Tarwater is forever altered by what this man does to him. To make use of Heidegger's phrase, he is knocked into finitude. That is to say, Tarwater is humbled and thereby recognizes that he is subject to God's laws, and this he is certain of: "He [knows] that he [cannot] turn back now. He [knows] that his destiny forced him on to a final revelation" (473). Due to this most disturbing and humiliating event, Tarwater sacrifices himself and accepts his calling by faith.

Tarwater arrives at Powderhead and sees his great-uncle's grave properly mounded. Upon seeing this completed work, he feels "as if he were dropping something 
he had been clutching all his life" (477). Tarwater returns home as a Christian boy who is tried and thus fully aware and accepting of his ministerial charge, but in this instant he is no longer confounded by his great-uncle's duplicity because he has the capacity now to discern truth from error, righteousness from unrighteousness. That is to say, he has the mental ability to review previously-learned beliefs in the light of new revelation from God. However, this is not to assert that Tarwater is walking in complete certitude, for the doubtful voice of the stranger suddenly surfaces. It whispers, "We've won [Powderhead]. Ever since you first begun to dig the grave, I've stood by you, never left your side, and now we can take it over together, just you and me. You're not ever going to be alone again" (475). Because Tarwater is a Christian walking by faith, his doubts will always remain. They are "as pervasive as an odor, a warm sweet body of air encircling him, a violet shadow hanging around his shoulders" (475). Nevertheless, Francis Tarwater has matured in the weeks after his great-uncle's demise so that his own inner-voice is no longer a friend but "his adversary" (475). It is an adversary, he now recognizes, that he must continually combat and suppress.

Since originally leaving Powderhead, Tarwater has been tried in a type of fining process, and what his tribulations ultimately yield is a determined Christian who is filled with the Spirit of God. His countenance, which is unmistakable to those around him, now seems "to pierce the very air" (477). An acquaintance of Tarwater, Buford, in fact sees the young boy's gaze and grows uneasy. It is the look of a selfless prophet who is dead to dear desire: "Nothing seemed alive about the boy but his eyes and they stared downward...below the surface of the earth to where its roots encircled the dead" (477). No longer in the proverbial slough of despond, Tarwater is now following the Lord's will 
of his own volition —all else is unsatisfying and vain. He is content and wholly without pretention, for he knows that he is building upon the foundation of the Biblical prophets, "whose lives were chosen to sustain [the gospel], who would wander in the world, strangers from that violent country where the silence is never broken except to shout the truth" (478). 
Chapter V: Conclusion

A literary text is in part a product of an author's environment. Graham Allen even argues that "the text is not an individual, isolated object but, rather, a compilation of cultural textuality" (36). In Flannery O'Connor's most complex work The Violent Bear It Away, O'Connor creates a text that is deeply connected to Protestant Christianity and, thus, the culture of South. The protagonist's experiences are indeed an extremely distorted picture of a Christian's training in the South, but Tarwater typifies Southern Christianity nonetheless. In each of the above stories, in fact, O'Connor creates rather distorted and extreme pictures that do typify the South. Her vivid and often brutal religious characterizations allow her to both write creatively and fulfill her determination as a Catholic witness.

Flannery O'Connor's determination as an artist is clear. In a letter to a friend, O'Connor boldly states that the Catholic Church has inspired her with direction and purpose as a creative writer: "I write the way I do because (not though) I am a Catholic." She adds that her stories are indeed exaggerated and "hard," but not at all abstract: "The stories are...hard because there is nothing harder or less sentimental than Christian realism. I believe that there are many rough beasts now slouching toward Bethlehem to be born and that I have reported the progress of a few of them" (Habit 90). In many ways, O'Connor is the prophet Francis Tarwater. That is, she is a person of faith who has experienced a great deal (e.g., the effects of lupus, criticism from those who are unfamiliar with her perspective, etc.) and has consequently developed the resolve to depict or proclaim religious truth to readers outside of the Church. In short, she is a “God-conscious writer” (O’Connor, Habit 90), and as such, her writing is a reflection of 
the invisible universe.

However, a very important facet of O'Connor's work, especially for those, I suppose, who lament the didactic nature of her fiction, is that her fiction details such a culturally-rich region of the U.S. O'Connor is hardly a regional writer in the traditional sense, for she says, "To my way of thinking, the only thing that keeps me from being a regional writer is being a Catholic" (104), yet it is undeniable that what stands out in her literature is Southern culture. Literary critic Tom Lutz defines a regionalist literary text as a text which dramatizes the many arguments alive in a culture, whether they are controversies "between and within classes, regions, sexes and communities, but not with the intention of resolving them" (28). He adds that instead a regionalist text vacillates "between the sides, producing, finally, a complex symphony of cultural voices and positions whose only resolution lies in the reader-writer compact to survey the fullness of the scene" (31). It is my contention, however, that Flannery O'Connor's literature stands apart from this. Her literature does so because instead of merely leaving readers with a sort of contrapuntal, indeterminate symphony of earthly voices, O'Connor's stories offer to those who are cognizant of Southern religious principles both traces and firm figures of celestial things. Resolution or truth can be found therein. 


\section{BIBLIOGRAPHY}

Allen, Graham. Intertextuality. London: Routledge, 2000. Print.

Authorized King James Version. Print.

Barthes, Roland. "The Death of the Author." Falling into Theory: Conflicting Views on Reading Literature. Ed. David H. Richter. Boston: Bedford/St. Martin's, 2000. 253-257. Print.

Coulthard, A. R. "From Sermon to Parable: Four Conversion Stories by Flannery O’Connor." American Literature. Vol. 55, No.1 (March 1983), pp. 55-71. Duke UP. Print.

Cooney, William. "Heidegger, Martin.” Encyclopedia of Death and Dying. Advameg, Inc. Web.

Gentry, Marshall Bruce. Flannery O'Connor's Religion of the Grotesque. Jackson: University Press of Mississippi, 1986. Print.

Gooch, Brad. Flannery: A Life of Flannery O'Connor. NY: Little, Brown and Co, 2009.Print.

Gordon, Sarah. Flannery O'Connor: The Obedient Imagination. Athens: University of Georgia Press, 2000. Print.

Eagleton, Terry. Literary Theory: An Introduction. Minneapolis: U of Minnesota P, 1983. Print.

Evans, Brad. Before Cultures. Chicago: University of Chicago Press, 2005. Print.

Feeley, Kathleen. Flannery O'Connor: Voice of the Peacock. New Brunswick, NJ: Rutgers University Press, 1972. Print.

Heidegger, Martin, and Joan Stambaugh. Being and Time: A Translation of Sein Und Zeit. SUNY series in contemporary continental philosophy. Albany, NY: State University of New York Press, 1996. Print.

Lévinas, Emmanuel. Totality and Infinity: An Essay on Exteriority. Pittsburgh: Duquesne University Press, 1969. Print.

Lutz, Tom. Cosmopolitan Vistas: American Regionalism and Literary Value. NY: Cornell UP, 2004. Print.

Mayer, David R. “Outer Marks, Inner Grace: Flannery O’Connor’s Tattooed Christ.” 
Asian Folklore Studies. Vol. 42, No. 1 (1983), pp. 117-127. Nanzan Institute for Religion and Culture. Print.

Mellard, James M. "Flannery O'Connor's Others: Freud, Lacan, and the Unconscious." American Literature. 61 (1989): 625-643. Print.

O'Connor, Flannery. Collected Works. New York, NY: Library of America, 1988. Print.

---. The Habit of Being: Letters. Ed. Sally Fitzgerald. New York: Farrar, Straus, Giroux, 1979. Print.

O'Connor, Flannery, and Rosemary M. Magee. Conversations with Flannery O'Connor. Jackson: University Press of Mississippi, 1987. Print.

Orvell, Miles. Flannery O'Connor: An Introduction. Jackson, MS: UP of Mississippi, 1991. Print.

Ruckman, Peter S. The Book of Job. $2^{\text {nd }}$ ed. Pensacola, FL: BBP, 1993. Print.

Spivey, Ted Ray. Flannery O'Connor: the Woman, the Thinker, the Visionary. Macon, GA: Mercer University Press, 1995. Print.

Sherry, Gerard E. “An Interview with Flannery O'Connor.” The Critic. XXI (June/July, 1963): 29. Print.

Wood, Ralph C. Flannery O'Connor and the Christ-Haunted South. Grand Rapids, MI: William B. Eerdmans Pub, 2004. Print. 